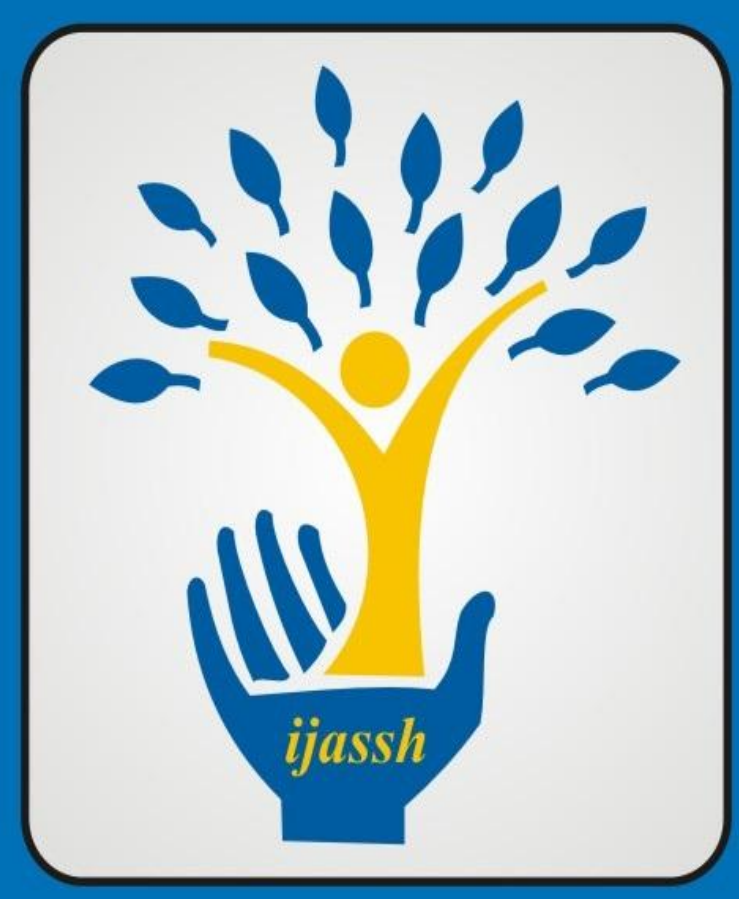

International Journal of Advances in Social Science and Humantities

\title{
IJASSH
}

www.ijassh.com 


\title{
RESEARCH ARTICLE
}

\section{Rational-Instrumental Action of Local People in Facing Flood}

\author{
Harifuddin Halim* \\ Pejuang University Republic of Indonesia Makassar
}

\begin{abstract}
The purpose of this study is to explore the rational-instrumental action in facing flood in Segeri village Indonesia. It is based on the premise that every society or community in facing floods certainly have selfstrategy with its consideration and its orientation. This research uses in-depth interviews to farmers in facing floods. Results of interviews that mapped are based on the indicators of 'rational-instrumental' action. This study found that the farmers as local people in Segeri village in facing flood as rationalinstrumental action, such as: making embankment in front of the house, elevating the pole house, preparing multi-function bamboo rest place, preparing the big rubber tires. All of those actions have 'rational-instrumental' aspects inside.
\end{abstract}

Keywords-Rational-instrumental, Action, Local people, Flood.

\section{Introduction}

Segeri village is an area that always gets flooded every year, especially during the rainy season. Due of the condition, Segeri people called their region as a 'local flood' that means Segeri identical to flooding and it is not Segeri when there is no flood during the rainy season. The main cause is Segeri located in low areas, close to the coast and mountains. Arfina [1] highlighted that the natural conditions also put in a flash flood region with the level of 'moderate' risk..

Floods that occur every year make people in Segeri village have respons experience. The experience raised from the interaction that takes place with the flood, with the same environments, as well as constructed by myth and a growing belief in it then led to an understanding of it as local knowledge. One of local knowledge at society of Segeri in is the flood name that occurred with its characteristics. For example, there is the socalled 'Wae pabbissa pennena balandae' that occurred at the end of December. There is a relation with the name to their. They also believe that the flood was due to the river dwellers 'angry', and also the will of God.

Based on local knowledge about flood and its characteristics, the farmers at Segeri village can anticipate and respons the effects of the flood. For example, before the coming of 'Wae pabbissa pênnena balandae' as flash flood, they put the seeds early so that they can raise seedings before the flood came. Another action is raising the easy wet goods to the higher place when the floods come at midnight.

The above description illustrates that Segeri community has its own ways and mechanisms in the face of floods in various forms. The ways and the mechanism born from experience of Segeri society over the years that passed on to the next generation. An experience is always born from the 'trial' and 'error' or ongoing trial in a recurring situation.

In an experience, the process of conducted trial always indicated the element of 'consideration' concerns the efficiency, effectiveness, use of the means to achieve goals. In this context, an act categorized as 'rational'. This description usher in a statement that Segeri community had the means and mechanisms of its own in facing floods based on experience gained by generations and tested from time to time based on their social and environmental conditions. 


\section{Rational-Instrumental Action and Local action}

According to Veeger [2], Giddens [3], Laeyendecker [4], Ritzer [5] that Weber introduces two types of rationality. First, rationality-purpose tool (Zweckrationalität) or action "is determined by the hopes of the behavior of objects in the environment and other human behaviors; the hopes was used as "conditions" or "tools" for achieving the objectives of the actor himself who pursued and taken into account rationally. Secondly, rationality of value (Wertrationalität), or action "is determined by the belief that conscious of its own value a form of behavior that is aesthetic, ethical, religious, or any other form, regardless of the prospects of success. In the local community action, Deloria[6], Basso[7], Pierotti and Wildcat[8] all action is almost tied to a specific location where people are being considered to make their dwellings and particularly for their way of life.

\section{Methodology}

This informant here is paddy field farmers. They interviewed deeply about their local actions related to the flood. To support the interview, it also conducted the study of literature from; research, books, and journals. The data analysed by using interpetation method.

\section{Results and Discussion}

\section{Segeri Flood History}

Observation of the flooding that has occurred previously either by the same person or by parents earlier been done by many Segeri people. The observation was ultimately gave birth to an experience in certain aspects have become well-established local knowledge and on other aspects continues to change and progress.

The three types of flooding are known in the community Segeri people, namely: flash flood, moderate flood and small flooding. All the floods had their own events by month. All flooding also occurred from the entry of the rainy season until the end of the rainy season, except in June and October. Categorizing flooding into three sections based on the flood situation and its impact, namely:
- The category of 'great flood' (flash flood) always soak houses including the provincial road in higher position than houses. Floods like this automatically has high water volume with velocity flow, potentially making landslides river banks and in certain cases can take casualties.

- The category of 'moderate flood' it does not soak the house, the water level can reach the human knee, the water is not too heavy.

- The category of 'small flood' is more puddles and sometimes to ankle height humans, the water quickly receded within hours.

The description above implies one important thing that Segeri people have local knowledge of flood classification and its impacts. Islam [9] highlighted that through observations, people know how to face the coming flood. Local knowledge is more 'specific' in the form of predictive and technical skills.

Fabiyi [10] researched that the Segeri people's situation is also occur in ethnic communities Ilajes, Its hekiries, and Ijaws in Nigeria's coastal rivers that also have the skill to predict the flood that has lasted and grown for years and are hereditary. It is also state by Dekens [11] by his founding that the Nepal Terai ethnic communities which for years suffered flooding to make their own local knowledge to survive from the flood.

\section{Kinds of Rational-Instrumental Actions}

Segeri people have local knowledge in anticipation of various flooding types and its effects. Anticipation is done through the identification and monitoring of local indicators which raising certain actions as the product of an analysis of the possibilities that will arise when the flood occurred. This is also confirmed by Fabiyi [12] that each community have special signs and techniques in determining the type and the extent of flooding.

Various anticipatory action undertaken by the Segeri people to face flood during the rainy season. They have managed to prevent them from disruption and threat to their live 
comfort. The anticipatory measures arise from the people's interpretation of interaction with flood they have faced. Anticipatory actions are as follows:

\section{Building an Embankment in Front of the House}

Making embankment around the house is one practical way preventing flooding into the driveway of the home and even in the home. This action is carried out by almost all Segeri people based on the condition of the area and the position of each house both domiciled in the city center and on the outskirts.

For those who live in the city center, the entire residential or home store has a permanent buildings or stone homes. Types of housing such as this is the most prone to accept flooding, especially in the rainy season. Anticipating the impact of floods wider, they make a simple high embankment that is not reached by the average floods.

The same actions committed by those who live in suburban areas. Generally, homes in this region are the home stage with different variations. Variations mean residents also take advantage of the lower floor as a multifunction space such as living room, rest room, a storage room or livestock.

Anticipatory action performed above admittedly be temporary. Scale flood addressed is still small because the flooding type is the most common. For large-scale flooding, the production of the concrete levee is unusefull.

\section{Raising the Pole House}

Other actions that are adaptable to the flood is raising the pole house by put big stone under the pole. This strategy is done by many people not only in Segeri village but almost by all the people who have houses pole.

For Segeri people, raising the pole house indirectly tend not only to avoid the reach of the flood. But, it tended to maintain the balancing of their house standing. It has a rational reason that the house pole position would be change and in imbalance for along time. There are seems often a lot of houses in unbalancing standing that could potentially cause the house falling and collapse.

In its process, the people adaptation's action above benefits them indirectly on the other side that is safe from the reach of the flood. Sometimes flooding that occurred in Segeri, indirectly cause the community can do more things and prepare themselves so 'bothered' by the floods indirectly, especially smallscale flooding and moderate scale, including large scale.

\section{Enhance the Base Floor of House}

Enhance basic floor of the house was also carried out by Segeri people for both house types, the stilts house and the stone house. However, those concerned significantly to enhance the base floor of the house is the owner of the permanent home. This is mostly due to considerations in anticipation of the coming flood.

Actually, all Segeri people want to heighten their basic floor's house. However, the action or strategy is not necessarily directly can they achieve because it requires a lot of consideration especially financial reasons. Therefore, many permanent homes do not have time to heighten its basic floor's house so that owners still try harder to adapt before the flood came.

The Segeri people heighten not only the permanen house, but also the home stilts. Before they built his house, they hoards by using mountain land at that location approximately 1-1.5 meters high from the top surface of the highway.

\section{Creating a Multi-Function Bamboo Resting Place}

Bamboo resting place is one of the 'property' with many benefits not only for people in the village, but also for people in urban areas. One of the main benefits is as a resting place of people, therefore bamboo resting place mostly located in the shady yard with trees. For residents in the village who generally have bamboo houses on stilts, the bamboo resting place is kept under the house. 
For Segeri people, bamboo resting place does have many functions. Therefore, in almost every house there are bamboo resting place in various sizes. The measure relating to the capacity of people who can sit on it, ranging from 5 people upwards. When the bamboo resting place is expected to be used by one family then it just made simple. But, when it will be used for certain purposes as a hangout by many people and it will be made as good and as strong as possible with the material of bamboo is strong.

Advantages possessed by the bamboo resting place is, it can be raised by man because they are lightweight and therefore can be moved wherever anything needs, including its material that is also durable as they are made of bamboo made pitches.

When the floods came, the Segeri people rely heavily on the bamboo resting place. It can be a 'savior gods' belongings were submerged in water. In this context, people actions who take advantage of the existing equipment called 'coping strategy'.

\section{Preparing a Giant Rubber Tires}

For people who access their homes far enough from the highway crowded with vehicles, making tires rubber as one of the 'property' they most need in flood time, especially those categorized as moderate or great flooding.

Giant rubber tires also basically has a function that is not much different from the halls of bamboo. It can be used as a place to accommodate the goods in limited quantities. However, the rubber tires can only be used more functional in the event of flooding after the wind filled.

One of the main advantages of rubber tires especially the large model, it can be used as a means of transportation at the flood time. Put board on top of the tire allows the person sit on it without being exposed to water. In addition, the tire can also be used to transport the goods to move to a safer place.

When flood occur especially in the largescale, the rubber tires they rely on for conveyance of goods and transport for people from their homes to the highway with a distance of about 500 meters. In fact, with rubber tires that someone can earn additional income by price about 5000 rupiah each way. Therefore, it can be argued that providing rubber tires is an action in anticipating flood.

Descriptions above illustrate the actions of Segeri people that are 'strategic' and 'anticipatory' in facing the flood at various scales. Strategically, Segeri people action related to their efforts in improving the physical environment around them such as building the embankment in front of the house, raising their pole home, heightens the house ground floor although it is not specifically intended to anticipate flood. As 'anticipatory', the taken action can also intended to face the floods.

In the perspective of disaster management, anticipatory action is categorized as mitigation or prevention. Sadisun [13] said that its implementation was carried out before the arrival of the rainy season. Coburn, A.W. et.al. [14] highlighted that this kind of action is basically oriented on the adaptation of the community, especially to the potential risk of floods and aim to reduce the effects of a hazard before the hazard occurred.

A number of studies on the actions or behavior of people faced floods demonstrated the efforts that are 'practical' or 'pragmatic'. For example, research Triuri [15] proved that the majority of people have adaptation strategies with high category. People who choose not move from the disaster area, do much the technical adaptation strategies, such as creating embankments, storing items in high places, and elevating homes.

Khasan and Widjanarko [16], Marschiavelli [17] state that other studies about the community response to flood find a number of their adaptive actions:

- Put the electronic goods to a higher place.

- Bind the goods to tree and pole or crocheted spikes

- Save the goods and securities. 
- Turn off the electric power and indeed when flooding occurs relevant officers already shut off in advance of its source.

- Assembling a flatboat of bamboo, a flatboat of banana stems, or a flatboat of a car tire rubber.

- If the flood becomes greater then all people are required to evacuate in a safe place. Overall, 'rational-instrumental' in this paper is also available to Willison's [18] state that local communities take measures to manage risks long before the hazards strike.

\section{Conclusion}

This paper explains that for Segeri people, flooding is not a major problem because it remains a positive impact. Nevertheless, the

\section{References}

1. Arfina, et.all. (2014). Spatial Analysis to Determine Flash Flood Disaster Risk Zone (Case Study at Pangkep District). 2014 Proceedings Seminar of the National Geophysical Science and Application Optimization In Makassar Improvement of Competitiveness of Nations.

2. Veeger KJ (1985) The Social Realities. Jakarta: PT. Gramedia.

3. Giddens Anthony (1986) Capitalism and Social Modern Theory, Analysis to Marx, Durkheim and Max Weber Theory. $1^{\text {st }}$ Edition. Jakarta: UI Press.

4. Laeyendecker (1983) Order, Change and Inequality (An Introduction to History of Sociology). Translated by: Samekto, from the original title: Orde, Verandering, Ongelijkheid: End Inleding in de Geschiedenis van de Sociologie. Jakarta: PT. Gramedia Pustaka Utama.

5. Ritzer George (1992) Sociological Theory. Singapore: Mc. Graw-Hill Book Company.

6. Deloria V (1992) The Spatial Problem of History, in God is Red, North American Press, Golden, CO, p.114-134.

7. Basso K (1996) Wisdom sits in Places, University of New Mexico Press, Albuquerque, NM.

8. Pierotti R, Wildcat D (2000) Traditional ecological knowledge: The third alternative, Ecological Applications 10:1333-1340.

9. Islam Muhammad Shariar (2007) Indigenous Knowledge and Natural Disaster Preparedness in Char Land of Bangladesh. Dissertation Script. Submitted to the Development Studies Program, BRAC University in Partial fulfillment of the requirement for the degree of Master of

10. Dekens, Julie (2007) The Snake and the River Don't Run Straight-Local Knowledge on Disaster Preparedness in the Eastern Terai of Nepal. International Centre for Integrated Mountain Development (ICIMOD) Kathmandu, Nepal. negative impact of flood should still be anticipated. Through local actions with rational-instrumental aspect, Segeri people can reduce the negative risk of flooding.

Therefore, the findings in this study may be considered by the government that local people generally have their own way in anticipation of the negative impact of the floods. So that, there are some recommendations as follows: (a) The government needs to do a mapping of local knowledge of society. This could support the government action in anticipation flood. This also involves the society to participate in government program. (b) It needs to integrate between the local knowledge, technology and modern science especially in anticipating the risk floods. (c) The government needs also to documentation the specific local knowledge.

11. Fabiyi Oluseyi Olubunmi, Joseph Oloukoi (2013) Indigenous knowledge system and local adaptation strategies to flooding in coastal rural communities of Nigeria. Journal of Indigenous Social Development. Volume 2, Issue 1.

12. Fabiyi Oluseyi et.al (2012) Integrative Approach of Indigenous Knowledge and Scientific Methods for Flood Risk Analyses, Responses and Adaptation in Rural Coastal Communities in Nigeria. Final Project Report for 2011 START Grants for Global Change Research in Africa. START-RECTAS.

13. Sadisun IA (2004) Disaster Management: Life in Regional Strategy for Disaster Potential. Keynote Speaker At Workshop Care Disaster and Environmental Geology. Geological Research and Development Center, Bandung 2-3 December 2004.

14. Coburn AW et.al. (1994) Disaster Mitigation. UN Development Program Collaborating with the United Nations Disaster Relief Coordinator office for Disaster Management Training Program collaborating with University of Wisconsin Disaster Management Centre.

15. Triuri Zelina, Djaka Marwasta (2012) Community Adaptation Strategies in Facing Flood in Tebet, South Jakarta (Case Study Regional Ciliwung River Plate). Journal of the Earth Indonesia, Volume 1 No. 3.

16. Khasan, Widjanarko, (2011) Coping Behavior Society Facing Flood. The Pitutur Journal of Psychology Volume I, No. 2.

17. Marschiavelli Mone Iye Cornelia. (2008) Vulnerability Assesment and Coping Mechanism Related to Floods in Urban Areas: A Community-Based A Case Study in Kampung Melayu Indonesia. Thesis. Post-Graduate School Gadjah Mada University:

18. Willison Zenaida Delica (2005) Community-Based Disaster Risk Management: Local Level Solutions to Disaster Risks. Tropical Coast, p. 8. 